\title{
Managing climate change in conservation practice: an exploration of the science-management interface in beech forest management
}

\author{
Jessica de Koning • Esther Turnhout • Georg Winkel • \\ Marieke Blondet · Lars Borras • Francesca Ferranti • Maria Geitzenauer • \\ Metodi Sotirov $\cdot$ Alistair Jump
}

Received: 3 March 2014/Revised: 4 August 2014/Accepted: 16 August 2014/

Published online: 28 August 2014

(C) Springer Science+Business Media Dordrecht 2014

\begin{abstract}
Scientific studies reveal significant consequences of climate change for nature, from ecosystems to individual species. Such studies are important factors in policy decisions on forest conservation and management in Europe. However, while research has shown that climate change research start to impact on European conservation policies like Natura 2000, climate change information has yet to translate into management practices. This article contributes to the on-going debates about science-society relations and knowledge utilization by exploring and analysing the interface between scientific knowledge and forest management practice. We focus specifically on climate change debates in
\end{abstract}

Communicated by Georg Winkel.

J. de Koning $(\bowtie) \cdot$ E. Turnhout

Forest and Nature Conservation Policy Group, Wageningen University, P.O. Box 47, 6700 AA Wageningen, The Netherlands

e-mail: Jessica.dekoning@wur.nl

G. Winkel · L. Borras · M. Sotirov

Forest and Environmental Policy Group, Institute of Environmental Social Sciences and Geography, University of Freiburg, Tennenbacher Str. 4 (4.OG), 79106 Freiburg, Germany

M. Blondet

AgroParisTech - ENGREF, Centre de Nancy, 14 rue Girardet CS 14216, 54042 Nancy cedex, France

F. Ferranti

European Forest Institute Central Regional Office (EFICENT), Wonnhaldestr. 4, 79100 Freiburg, Germany

M. Geitzenauer

EFICEEC - European Forest Institute Central-East European Regional Office, c/o Institute of Forest, Environmental and Natural Resource Policy, Department of Economics and Social Sciences, University of Natural Resources and Life Sciences Vienna (BOKU), Feistmantelstr. 4, 1180 Wien, Austria

A. Jump

Biological and Environmental Sciences, School of Natural Sciences, University of Stirling,

Stirling FK9 4LA, UK 
conservation policy and on how managers of forest areas in Europe perceive and use climate change ecology. Our findings show that forest managers do not necessarily deny the potential importance of climate change for their management practices, at least in the future, but have reservations about the current usefulness of available knowledge for their own areas and circumstances. This suggests that the science-management interface is not as politicized as current policy debates about climate change and that the use of climate change ecology is situated in practice. We conclude the article by discussing what forms of knowledge may enable responsible and future oriented management in practice focusing specifically on the role of reflexive experimentation and monitoring.

Keywords Climate change $\cdot$ Forest management - Natura $2000 \cdot$ Science management interface $\cdot$ Knowledge utilization

\section{Introduction}

Discussions about the impacts of climate change in the context of nature conservation are moving forward quickly. Understanding and predicting impacts of climate change on living systems is a core focus of much research in biological and environmental sciences (see for example Walther et al. 2002; Parmesan 2006; Peñuelas et al. 2013). These studies reveal the general consequences of climate change for natural and semi-natural ecosystems. For example, climate change effects entail the advance of spring events, lifecycle asynchrony between interacting species, shifts in ranges, relationships of parasites and human diseases, and more (Parmesan 2006). Many such changes have already been documented, from changes in ranges and abundances of species (Walther et al. 2002; Parmesan 2006) to alteration in growth, productivity, and reproductive capacity of populations across the globe (Parmesan 2006; Peñuelas et al. 2013). However, the locally specific effects of increased temperatures vary across the distribution of any given species affecting the dynamics in species composition and interspecific competition (Woodward 1987; Pigott and Pigott 1993).

In the context of varying effects of climate change, climate change ecology has increasingly become an important factor to underpin conservation and management decisions (Hagerman et al. 2010). This is not a new phenomenon, ecological science is known for its long history of influencing policy (Lawton 2007). Commonly proposed policy measures and means to respond to the identified climate change effects relate to the ecological recommendations to expand protected areas, and create ecological corridors of buffer areas adjacent to and in between conservation areas (Hannah et al. 2002; Hannah 2008; Felton et al. 2009; Milad et al. 2011). In other words, the emphasis is on expanding protected areas and enhancing connectivity to ensure species migration and genetic exchange. These recommendations and the knowledge underpinning them seem to have had an effect on conservation policy. For instance, climate change is explicitly linked to German forest conservation policy (Winkel et al. 2011) and the European network of nature areas: Natura 2000 (De Koning et al. 2013). However, these examples of knowledge utilization are fairly general and they say little about the ways in which this knowledge is enacted in management practice. It may well be that its relevance and usefulness is restricted because it often does not tackle the locally specific effects of climate change and their associated variation. This unpredictable character of climate change implies that 
forest and natural area managers do not have a clear outlook on what precisely will happen in their areas as a result of climate change (Wagner et al. 2014). Moreover, management practices may be institutionalized and historically and culturally embedded and consequently prove difficult to change on the basis of scientific information (Arts et al. 2013).

These considerations warrant further investigation of what happens at the interface between climate change ecology and conservation management. In doing so, we contribute to a growing body of knowledge that has looked at science-society relations and knowledge utilization (Lawton 2007; Jones et al. 1999; Walton and Gray 1991). Specifically, by focusing on the science-management interface we complement studies that hitherto have focused largely on science-policy interfaces (Cash et al. 2003; Wesselink et al. 2013; Turnhout et al. 2008), and we take up the challenges identified in literature (Beck 2011; Robertson and Hull 2001; Turnhout et al. 2013b) to put more analytical effort into exploring the knowledge needs of conservation and management practitioners and better attune scientific knowledge making efforts to local action. For this purpose we ask the following questions: how does climate change ecology connect with local conservation and management practices and what knowledge needs can be identified at the science-management interface? In this article, we specifically look at local case studies of European beech (Fagus sylvatica) conservation within the European Union's Natura 2000 network of protected areas (Europe's most important nature conservation policy framework). Beech forests fit the objective or our paper because they are a key habitat under Natura 2000 and they are also rather sensitive to climate change.

We analyse the science-management interface by assessing the different existing perceptions on forest management practices and the effects and uncertainties climate change brings. We do this by first discussing relevant insights from studies about science-society relations and the potential of the science-management interface in the context of climate change (see section "Knowledge utilization in policy and in management"). Following an overview of research methods (see section "Methodological approach"), we then move on to present a summary of ecological effects of climate change for beech forests and their links with European forest policy (see section "Climate change ecology and policy debates in Natura 2000"), and describe the local perspectives of local forest managers on climate change, forest management practices and scientific knowledge (see section "Beech forest conservation in practice"). We conclude with a summary of the functioning of the sciencemanagement interface and its potential in the climate change discussions (see section "Actionable knowledge for conservation management: towards reflexive monitoring and careful experimentation”).

\section{Knowledge utilization in policy and in management}

Scientific and policy discussions of sustainability and environmental governance increasingly focus on the question of knowledge (Beck 2011). As scientific knowledge is traditionally regarded as a crucial input for policy making, it follows that an effective sciencepolicy interface is often seen as an important condition for enhancing sustainability (Petrokofsky et al. 2013; Turnhout et al. 2013b). These messages are also found in conservation biology (see for example Hunter 1996; Meffe 1998; Robertson and Hull 2001). This finding is not surprising since conservation biology is often described as a missionoriented discipline that aims to produce scientific knowledge in order to contribute to the conservation of nature and biodiversity. These sentiments are clearly reflected by Robertson and Hull (2001, p. 978) when they state that the "goal of conservation biologists 
should be to make the science of conservation biology more relevant to the regulation, politics, management and litigation of biological conservation".

For science to make such a contribution to policy, the science-policy interface needs to be effective. However, forging mutually fruitful relationships between science and policy has proven to be a difficult task (Boehmer-Christiansen 1994). Several conditions for knowledge use and productive science policy interfaces have been identified that emphasize the importance of, amongst others, (1) credibility, relevance and accessibility of knowledge, (2) the communication skills of knowledge producers, and (3) the receptiveness of knowledge users (Jones et al. 1999). Apart from these obvious challenges, it must be recognized that, in general, scientific knowledge does not unequivocally translate into alternatives for action, and that policy makers have to be responsive to a wide variety of inputs, of which scientific knowledge is only one, and often not the most important one (Boehmer-Christiansen 1994; Lawton 2007; Walton and Gray 1991; Wesselink et al. 2013). Moreover, research on the science policy interface in the environmental domain has shown that this interface of knowledge and policy is dynamic, and characterised by complex interactions between knowledge producers and users that result in policy alternatives with markedly different outcomes. These outcomes range between those rare cases of instrumental take up of knowledge, to use of scientific concepts and ideas to accommodate conflict and facilitate political compromise, to controversies in which the opponents use competing knowledge claims to underpin their respective positions (Turnhout et al. 2008; Sarewitz, 2004; Memmler and Winkel 2007). This process, dubbed the politicization of scientific knowledge (Weingart et al. 2000), has the potential to significantly hamper effective knowledge utilization (McCright and Dunlap 2011).

These findings, together with the general idea that policy decisions do not implement themselves but require active translation into practice, warrant further exploration of other avenues in which scientific knowledge might have a role to play. In the case of conservation, it is therefore important to look not only at what happens at the science-policy interface but also to consider the science-management interface. Although research on the science-management interface is increasing, it is still less common compared to the science-policy interface (Roux et al. 2006). Studies by Bocking (2004), Bradshaw and Borchers (2000) and Roux et al. (2006) suggest that knowledge flows between scientists and local forest managers are complex and that barriers to knowledge use between science and practice might differ from the science-policy interface in important ways. These differences can be related to the inherently practical character of management. While in policy debates, scientific knowledge often plays an important role in defining a policy problem, setting the political agenda, or legitimizing policies; management practices are more acutely confronted with the question of "what to do out there". In such a comparatively less politicized context, the "big" questions of whether climate change is real and how societies and policies can or need to respond to it arguably matter less, and practical action and day to day decision making take centre stage. This practical action is inevitably influenced by a wide variety of — often tacit—knowledges and considerations (see Cortner and Moote 1999 for a relevant overview of the multiple factors that influence current day ecosystem management). In other words, while policy makers are embedded in the "political", forest managers are embedded in the "practical".

Consequently, one may argue that management practice is perhaps a more relevant recipient of scientific knowledge than policy because management is faced with the need to draw practical decisions in order to make progress in adapting to climate change. In light of the important potential of conservation management as a productive avenue in which scientific knowledge can be connected with meaningful action on the ground 
(Sutherland et al. 2004), it is vital to further explore what happens at the interface between science and management, including potential barriers for knowledge use.

\section{Methodological approach}

In the following sections, we first summarize the impact of climate change on Beech forests and policy responses to climate change in Natura 2000 to identify the role of scientific knowledge on climate change in forest and nature conservation issues with a focus on ecological effects and policy responses. Subsequently, we present the findings from a selection of interviews in local cases of beech forest conservation in Austria, Germany, France, Netherlands, Spain and the United Kingdom. These interviews are part of a large international comparative research project. In this framework of research, 188 (semi) structured interviews were conducted between 2011 and 2012 with relevant stakeholders at different administrative levels such as forest managers, private owners, policymakers at different administrative levels, scientists, ecologists, etc. These respondents were selected because of their direct relation with the researched cases. The interviews included a set of questions about general issues of Natura 2000 implementation and forest conservation and management and the issue of climate change. Regarding climate change, two specific questions were asked: (1) How important is climate change in the context of Natura 2000 and forest management? (2) How does climate change affect your management and/or policy decisions? All interviews were recorded and transcribed.

For the analysis of the data, we focused on those interviews conducted with local forest managers that addressed climate change at the management level more specifically, beyond general and abstract statements. In this article, forest managers are those actors that are involved in forestry and nature conservation, owners of private forests and local forest management experts. This is a diverse group with different interests and ideas. On the basis of these criteria, 30 interviews were selected for further analysis. The fragments focusing on climate change were coded by the first author. Coding allows for categorization and abstraction (Miles and Huberman 1994; Spiggle 1994). Categorization included the responses to climate change, the importance of science, and the effect climate change has on forest management. This was followed by an abstraction of the categories into more general ones (Spiggle 1994). From this, three abstract categories emerged that were typical for the whole interview fragment. These findings were then presented to and discussed with all project researchers/co-authors responsible for data collection to ensure validation of the results.

\section{Climate change ecology and policy debates in Natura 2000}

In spite of a certain consensus on the general effects of climate change, discussion about uncertainties and the complexity of climate change remains. There is the general issue of uncertainty related to climate change predictions themselves that can only be made based on modelling. In general terms, however, the poleward extent of a species is commonly determined by low temperatures, whereas in the opposite (equatorial) direction, unfavourable water balance often limits the species spread. Additionally, interspecific competition can play an important role at both margins (Woodward 1987; Pigott and S, 1993). Whereas increasing temperatures can drive the expansion of populations towards higher altitudes and latitudes at the advancing edge of the species geographical distribution, 
growth decline and population retreat is more commonly reported at the low altitude/low latitude margin (Jump et al. 2009). Yet it remains difficult to exactly predict or single out the climatic effects on forest and nature conservation, as there are many additional factors, including competition, land use, soil type, pests and pathogens that act individually and in combination to influence, for example, the distribution and dynamics of a species (Davis et al. 1998; Pearson and Dawson 2003). Consequently, despite relatively clear general predictions of climate change impacts at a regional scale, it is difficult to scale precise predictions to population level due to high spatial and/or temporal variability in local weather and interacting factors such as those outlined above (Jump et al. 2010).

Yet, regardless of these uncertainties related to climate change and its impacts, there is consensus that-amongst temperate deciduous broadleaved trees-European beech is particularly drought sensitive, making this species highly susceptible to increasing drought intensity and duration associated with increasing temperatures throughout its range, but particularly at the southern range-edge of the species (Rennenberg et al. 2004; Geßler et al. 2007; Peñuelas et al. 2007; Kramer et al. 2010). Recent work across the equatorial range edge of this species has identified significant declines in the growth of adult individuals, with a substantial fall in recruitment also recorded in some of the same populations (Jump et al. 2006; Peñuelas et al. 2007; Piovesan et al. 2008; Barbeta et al. 2011; Maxime and Hendrik 2011). Such case studies highlight that populations at the southern margin of this species distribution are frequently highly ecologically marginal and many are unlikely to persist as the climate continues to warm (Kramer et al. 2010; Czucz et al. 2011). The combination of growth decline and reproductive failure of beech in some areas of its range is resulting in population decline and replacement by other species, as is already being witnessed in Catalonia where evergreen holm oak (Quercus ilex) dominated forest is replacing beech forest (Peñuelas et al. 2007).

Although species distribution models highlight the general vulnerability of southern range edge populations of beech to rising drought stress (Kramer et al. 2010), population decline is not predicted to be limited only to the very southern margin of its distribution, nor is universal decline across the southern range-edge of this species likely. Populations close to the geographical core of the species distribution are predicted to become ecologically marginal if water balance becomes unfavourable as the climate warms, for example where they occur on thin soils with low water-holding capacity (Rennenberg et al. 2004; Broadmeadow et al. 2005; Geßler et al. 2007). Indeed, recent work has highlighted that past severe drought has had a persistent impact on the growth of this species in its core distributional area (Cavin et al. 2013). In contrast, even in the very southern areas of this species distribution, relict populations may persist due to favourable microclimatic conditions (Jump et al. 2010; Hampe and Jump 2011). Furthermore, past management activity is likely to have altered both the distribution of populations and the longevity of individuals (Jump et al. 2009; Sjölund and Jump 2013). Consequently, anthropogenic impacts on the growth and distribution of this species add significant uncertainty to distributional shifts modelled using climate-based predictions (Chen et al. 2011; Rabasa et al. 2013). Whereas we know that there will be a general shift of this species distribution northward and upward in altitude as the climate warms, at the local level we cannot be certain about which populations will decline first or fastest without a substantial increase in detailed stand-level data (Jump et al. 2010).

Thus, based on the insights from climate change ecology, there are policy challenges pertaining to the effectiveness of beech forest conservation that require a response. These challenges are grounded in ecological knowledge, but have a clear (conservation) policy dimension as well. In the context of Natura 2000, two possible responses can be identified 
(De Koning et al. 2013). On one hand, policymakers have interpreted the challenge resulting from climate change as a plea for strengthening the implementation of the policy. In this line of thinking, the resilience of Europe's habitats must be increased by better protecting habitats against additional stressors resulting from habitat fragmentation, intensive land use for commodity production, etc. In line with this response, it is seen as an important, additional measure to increase ecological connectivity through protecting corridors and integrating conservation objectives in the management of areas outside the protection regime (Brooker et al. 2007; Cliquet et al. 2009a, b; Huntley et al. 2012). Yet, in this perspective, the basic concept of habitat and species protection under Natura is seen as adequate even under a changing climate This policy rationale is supported by arguments of conservation scholars that consider Natura 2000 protection to be feasible in a changing climate (Dodd et al. 2009; Ellwanger et al. 2012; Evans 2012).

On the other hand, other policy stakeholders use evidence of climate change ecology in a rather different way. In this perspective, Natura 2000 is frequently framed as being too static and inflexible given the predictions on changing environments as a result of climate change (De Koning et al. 2013). The central claim under this perspective is that a 'static' conservation of species and habitats at the place where they currently occur cannot be maintained with respect to climate change. This perspective argues for a flexible and arguably 'softer' implementation of Natura 2000 that leaves considerable scope for tailormade management decisions and measures. Again, this perspective can use conservation science arguments to back its arguments, as the Natura 2000 conservation framework is also seen as being too static by some conservation scholars that underline the necessity to revise it given the growing evidence of climatic changes (Cliquet et al. 2009a, b; Araújo et al. 2011).

Thus, each of these two policy responses can in principle be seen as a legitimate, rational, and science-based response to climate change. However, they have different consequences in practice and they are promoted by different groups of actors with different interests. While the first response is preferred by the European Commission, in particular the DG Environment, and Environmental Non-Governmental Organizations, the second response is preferred by forest land owners and other forestry actors (De Koning et al. 2013). The debates between these two responses and the actors promoting them illustrate the politicization of science at the science policy interface alluded to earlier. The point is not to claim that one or both of these coalitions misuse scientific knowledge to further their interests - although this may occasionally be the case-but rather to show that in a political context, scientific knowledge is ultimately ambiguous and can be legitimately used to underpin different policies, interests, and decisions.

\section{Beech forest conservation in practice}

The results of the interview data on practitioners' responses to climate change paint a different picture when compared to the rather polarized and policy discourses. First, practioners' responses do not reflect the identified challenges for beech management and conservation under climate change. Second, scientific recommendations for forest management apparently have not affected management practices much. Despite a great deal of research, and high profile debate, climate change is not a prominent topic amongst most practitioners and changes in management practices seem to be only weakly driven by scientific recommendations. In what follows we will discuss the three issues that were identified most in our data: (1) the complexity and uncertainty of climate change and 
concomitant scientific knowledge; (2) the embeddedness, or fixedness, of forest management practices; and (3) the role of practical expertise and knowledge.

First, uncertainty is a major component in the debates on climate change effect for forest managers as forest managers struggle with the abstract character and the long term planning climate change requires (De Koning et al. 2013; Hoogstra and Schanz 2008). Our findings suggest that the uncertainties involved in predictions about the local effects of climate change make it difficult for forest managers to prioritise climate change in their practices. Consequently, most of the interviewed forest managers do not consider climate change as an important issue that requires (immediate) action. ${ }^{1}$ As one of our respondents explained:

"Climate change is very slow. I think that this is not something that generally worries people in their everyday life. People can be curious but I am not sure if climate change is the main thing that the managers currently worry about." (Local forest researcher, Spain)

Many respondents argued that it is perhaps not very useful or effective to attempt to respond to climate change because of the overwhelming force of climate change and the uncertainties in scientific projections:

“.... I dońt know if we can fight against [climate change], from a practical point of view. I mean, it may all be very nice in a sort of academic way to say "it must be conserved as a beech forest". But historically, we know that planting beech on the site gives us good results, but if the climate is not going to help us, or deer damage is going to be too much, then we might be fighting a losing battle." (Forest manager, $\mathrm{UK})$

“.... how would one like to react in view of climate change? [...] There is basically no clear climate model that describes how it would look like here. There are only assumptions, but no there is no clear model. (Forest manager, Austria)

Although these quotations suggest that scientific knowledge is relevant, it is unlikely to be very influential in practice. Several forest managers feel that science has yet to come up with locally specific and updated information about what will happen in the forests:

"I have to say that I am not an expert. I cannot estimate [the consequences of climate change]. Of course, if the temperatures are increasing then everything moves into the higher alpine regions. This will clearly be an issue and will have an impact ... But how to deal with it practically? I don't know." (Forest manager, Austria)

"The main problem around the issue of climate change is that the scientific community still cannot offer practical recommendations at management level." (Local forest expert, Spain)

Thus, it seems that the available scientific knowledge does not match the perceived needs of forest managers. However, even if complete and detailed scientific knowledge were present, this does not mean that forest management practices are easily changed. Rather, change is difficult to bring about as there are costs involved and climate change adaptation generally requires a lot from forest managers in terms of effort, commitment

\footnotetext{
1 The low level of importance forest managers attribute to climate change in this selection of interviews $(N=30)$ is consistent with the low level of importance expressed by most interviewed stakeholders in the local case studies part of the large international comparative study $(N=188)$ (De Koning et al. 2013).
} 
and resources, which brings us to the second issue: the embedded character of management practices in forest and nature conservation. In this article, the concept of embeddedness follows the definition of 'situated agency' (Bevir 2005) and refers to the degree in which forest management practices are affected by routinized practices, resources, expectations, social and organizational structures and dilemmas. Many forest managers highlighted the somewhat limited room for manoeuvre that determines their ability and willingness to change management practices. These are expressed in the quotations below:

"Look, when we constructed the management plan, we already brought up the issue [of climate change]. It is getting worse with this climate change, the whole politics surrounding it, the intensity of it, so to say. There was a big party when we were done [constructing the management plan], but it is already outdated because of continuing changes. Imagine how outdated it will be in 10 years! And they [the forest organizations] really do not want to invest another $€ 100.000$ in a new plan." (Forest manager, the Netherlands)

"As long as nobody can tell me exactly in which direction the [climate change] development really goes, I think, I will not jump from one day to another [...]. So I say, let us wait for now. Waiting for too long is, I think, also not good. But to jump from one day to another with this level of climate knowledge and to say that this is what we do and we initiate programmes which will be effective for the next 120 years? That seems too risky to me!" (Forest manager, Austria)

Change is also difficult because of the wide variety of factors that influence management practices. Forest managers frequently collaborate with other stakeholders in and outside the forestry realm. This results in different factors that may impact on management practices and decisions. The next quote shows that decisions related to forest management also relate to the wider context of the landscape and different land use practices

\footnotetext{
"So, you use the expertise of different local organizations. [...] if you keep an eye out for climate change, you can take certain steps to diminish the damage or maintain the status quo. At least not make the situation become worse, you know. Look, it is a matter of time, but you do try to sketch an image of all the consequences based on what you know. What happens with the Broekbossen [wet forests], what happens with the Natte hooilanden [wet hay meadows], how are things with the nitrate emissions in agriculture? All these things have to be combined." (Forest manager, the Netherlands)
}

Taken together, our discussion on the current lack of practical solutions offered by science and the local embeddedness of forest management practices has implications for what type of knowledge is relevant for forest management. And with that we arrive at the third issue often mentioned by forest managers: practical knowledge and expertise. Over the whole, scientific knowledge is perceived to present only general solutions to general issues. It does not appear to connect to the particularities of forest management practices and some forest managers are becoming somewhat cynical about the value of scientific knowledge in the context of climate change:

"Nobody knows exactly what will happen in the future. It is good to talk about that, but you should not give ready-made solutions and generate slightly general cooking recipes that say: 'we need to plant cedar tree here, we need to plant that species there, or we need to clear cut the forest stand'." (Forest manager, France) 
Instead of waiting for complete and certain scientific information, several forest practitioners are even considering taking a more pro-active attitude and rely on their own expertise in thinking about other forest management practices in the context of climate change:

"I think what happens is that knowledge about species often is only so far as it got. And there are lots of other options and models and changes and things about climate in any particular year. And it's about the intensity of the operation or something else. But there shouldn't be too many restrictions because you miss opportunities. I definitely think that nature conservation is very much about precaution. And actually it should be much more opportunistic. It should be trying...trying lots of different things that fit lots of companies' or organizations' or owners' models. (Forest manager, UK)

"We should not only wait for scientific evidence but also experiment more to improve biodiversity in the light of climate change." (Forest manager, the Netherlands)

These quotations point to the importance of future oriented forms of experimentation in management practice where the active seeking of opportunities and the monitoring of the effects of these practices may be more important than accurate scientific predictions of climate induced changes. The knowledge needed to guide these practices is not just the product of scientific inquiry but requires input from conservation managers and has to build on existing practitioners' networks because, as the quotation below illustrates, good for collaboration:

Yes, [good relationships with other foresters] have huge advantages. Because you know them, we work in other areas together. [...] So it is really a quick phone call and they say "What does that mean for me? How do you see it? Would we, could we, should we?..." And that is a great advantage." (Forest manager, Germany)

The knowledge that is produced in these networks may not be able to predict the precise effects of climate change in different areas, but it does have the potential to be future oriented, actionable and linked to the lived experiences and daily realities of forest managers. We will discuss this issue further in the next section.

\section{Actionable knowledge for conservation management: towards reflexive monitoring and careful experimentation}

This article set out to explore the science-management interface in the context of forest management under climate change and compare this with the scientific and policy debates about climate change in the context of beech forest management under Natura 2000. A clear finding is that the climate change debates and the role of knowledge in it are affected by the great uncertainty that surrounds climate change. Scientific knowledge on climate change may be able to predict the general consequences of climate change with some degree of certainty, yet it cannot provide information on the effects at the micro level. We saw that among some forest managers, the uncertainties and ambiguities of climate change knowledge resulted, on one hand, in rather passive attitudes and even scepticism amongst forest managers towards scientific knowledge and European conservation policies. On the other hand, we also observed more future-oriented, pro-active attitudes among forest 
managers. These forest managers rely on their own expertise and networks to make forest management decisions and adapt to climate change in practice.

Our findings further suggest that the science management interface appears to be less politicized than science policy interfaces. Instead of polarized debates as for example documented in De Koning et al. (2013), we found the science management interface to be characterized by complexity and practicality. First, forest managers found it difficult to act upon the knowledge provided by climate change ecology, not only because it was not precise enough about the exact effects on their areas, but also because of a lack of practical recommendations to respond to climate change at the stand level. Second, forest management practices are seen by forest managers to be embedded in long-term professional routines and scientific knowledge could not be easily fitted into on-going daily practices and concerns. Third, forest managers have constructed their knowledge and experience, based on expertise and other inputs; they have specifically adapted to their situation and scientific knowledge does not always perfectly relate to it.

Thus, there are clear limitations to the relevance and usefulness of scientific knowledge for management practices. At the same time, there is a need to move forward and to come up with new perspectives for forest managers. We propose that, in a context of climate change and forest management, we perhaps need a different sort of knowledge: one that is produced and situated in management practice itself. As the availability of complete and precise knowledge is unlikely and perhaps even impossible, the ease with which knowledge can be translated into action necessarily overrides concerns over its accuracy and scientific validity (Palmer 2012; Turnhout et al. 2013a). Such actionable knowledge is less concerned with describing the system, identifying general patterns of causality or predicting future impacts of climate change, than with designing options, reflexively monitoring their effects, and adapting to changing circumstances. To be sure, we do not wish to downplay the importance of science in providing crucial insights into trends, patterns and changes in ecosystem. Rather, we argue that in the context of irreducible uncertainty and complexity, science is not sufficient as input for management practice (also see Cortner and Moote for a similar argument) and that we need more than just better communication, translation and integration of scientific knowledge as a solution for better knowledge uptake in management as is often suggested in the literature (e.g. Stevanov et al. 2013).

This idea of actionable knowledge fits well with the more pro-active and experimental forms of climate change adaptation that are advocated by some of our respondents. This suggestion also dovetails with current discussions about experimentation in conservation (Lorimer and Driessen 2013; Gross 2008; Gross and Hoffmann-Riem 2005) that also argue for a greater role of practical and local knowledge in conservation. As Lorimer and Driessen (2013, p. 10) put it: "ecological management [...] involves forms of practical expertise that are attuned to the diverse and surprising becomings of any ecological complex". The systematic monitoring of these experiments and interventions is of vital importance as this may generate knowledge about what works and under what conditions (Sutherland et al. 2004). Reflexive monitoring has two important characteristics when compared to dominant views of science (for a comprehensive overview see Van Mierlo et al. 2010). First, monitoring takes place in the direct context of the intervention and encourages all involved stakeholders to reflect on the different effects of management interventions. Second, it includes not just knowledge about nature, but also about social issues and the perspectives, values and ideas of all actors involved (Wadsworth 1998; Schut et al. 2011). Thus, reflexive monitoring has important potential to create inclusive processes that connect doing and knowing in locally meaningful ways. As the monitoring information and management interventions are necessarily the result of collaboration 
between scientists and managers, it is clear that the role of scientific experts in these processes changes from distant providers of knowledge to much more engaged roles of facilitators, brokers or participatory experts (Roux et al. 2006; Turnhout et al. 2013a).

Although these forms of knowledge and roles may be uncomfortable for many scientists and raise concerns related to independence and objectivity, they may be exactly what is needed for more effective conservation practice (see Robertson and Hull 2001 for a similar plea). Forest managers have innate knowledge about the small but crucial differences climate change can make to their forests and could augment our understanding of likely climate change impacts derived from more formal scientific study. Their knowledge, therefore, needs to be harnessed more effectively. Furthermore, the co-generation of knowledge, through reflexive monitoring, can contribute substantially to bridging the 'gap' between scientists and practitioners. As this article has shown, 'pure' science cannot solve the big uncertainties that surround climate change and that we should not strive for ever more accurate predictions alone. Instead, what is needed are news ways of thinking about connecting knowledge and action. It was Hagerman et al. (2010) that stated that climate change requires a reconsideration of conservation objectives. We wish to add to this statement that it also requires a reconsideration of climate change knowledge, its most relevant recipients, and concomitant roles of science.

Acknowledgments The data used for this paper were collected within the European BeFoFu project (www.befofu.org). BeFoFu is funded by national funding agencies (Austrian Wissenschaftsfond, the French Agence Nationale de la Recherche, the German Federal Ministry of Education and Research, The Netherlands Organisation for Scientific Research, the UK Natural Environment Research Council and the UK Department for Environment, Food, and Rural Affairs). We are grateful to our funders and the experts that devoted their time for the interviews.

\section{References}

Araújo MB, Alagador D, Cabeza M, Nogués-Bravo D, Thuiller W (2011) Climate change threatens European conservation areas. Ecol Lett 14:484-492

Arts B, Behagel J, van Bommel S, de Koning J, Turnhout E (2013) Prelude to practice: introducing a practice based approach to forest and nature governance. In: Arts B, Behagel J, van Bommel S, de Koning J, Turnhout E Forest and nature governance: a practice based approach. Springer, Dordrecht, pp 3-22

Barbeta A, Penuelas J, Ogaya R, Jump AS (2011) Reduced tree health and seedling production in fragmented Fagus sylvatica forest patches in the Montseny Mountains (NE Spain). For Ecol Manage 261:2029-2037

Beck S (2011) Moving beyond the linear model of expertise? IPCC and the test of adaptation. Reg Environ Change 11:297-306

Bevir M (2005) New labour: a critique. Routledge, London

Bocking S (2004) Nature's experts. Science, politics and the environment. Rutgers University Press, Piscataway

Boehmer-Christiansen S (1994) Global climate protection policy: the limits of scientific advice: Part 1. Glob Environ Change 4(2):140-159

Bradshaw GA, Borchers JG (2000) Uncertainty as information: narrowing the science-policy gap. Conserv Ecol 4(1):7

Broadmeadow MSJ, Ray D, Samuel CJA (2005) Climate change and the future for broadleaved tree species in Britain. Forestry 78:145-161

Brooker R, Young JC, Watt AD (2007) Climate change and biodiversity: impacts and policy development challenges-a European case study. Int J Biodivers Sci Manage 3(1):12-30

Cash DW, Clark WC, Alcock F, Dickson NM, Eckley N, Guston DH, Jäger J, Mitchell RB (2003) Knowledge systems for sustainable development. Proc Natl Acad Sci USA 100(14):8086-8091

Cavin L, Mountford E, Peterken G, Jump AS (2013) Extreme drought alters relative competitive dominance within and between species in a mixed forest stand. Funct Ecol 27(6):1424-1435 
Chen IC, Hill JK, Ohlemüller R, Roy DB, Thomas CD (2011) Rapid range shifts of species associated with high levels of climate warming. Science 333:1024-1026

Cliquet A, Backes C, Harris J, Howsam P (2009a) Adaptation to climate change Legal challenges for protected areas. Utrecht Law Rev 5(1):158-175

Cliquet A, Harris J, Howsam P, Backes C (2009b) Response to 'protected areas and climate changereflections from a practitioner's perspective' Utrecht Law. Review 6(1):149-150

Cortner H, Moote MA (1999) The politics of ecosystem management. Island Press, Washington

Czucz B, Galhidy L, Matyas C (2011) Present and forecasted xeric climatic limits of beech and sessile oak distribution at low altitudes in Central Europe. Ann For Sci 68:99-108

Davis AJ, Jenkinson LS, Lawton JH, Shorrocks B, Wood S (1998) Making mistakes when predicting shifts in species range in response to global warming. Nature 391:783-786

De Koning J, Winkel G, Sotirov M, Blondet M, Borras L, Ferranti F, Geitzenauer M (2013) Natura 2000 and climate change-polarization uncertainty and pragmatism in discourses on forest conservation and management in Europe. Environ Sci Policy. doi:10.1016/j.envsci.2013.08.010

Dodd A, Hardiman A, Jennings K, Williams G (2009) Commentary protected areas and climate change Reflections from a practitioner's perspective. Utrecht Law Rev 6(1):148

Ellwanger G, Ssymank A, Paulsch C (eds) (2012) Natura 2000 and climate change a challenge. Bundesamt für Naturschutz, Naturschutz und Biologische Vielfalt Bonn

Evans D (2012) The habitats of annex I and climate change. In: Ellwanger G, Ssymank A, Paulsch C (eds) Natura 2000 and climate change A challenge. Bundesamt für Naturschutz, Naturschutz und Biologische Vielfalt Bonn, pp 73-81

Felton A, Fischer J, Lindenmayer D, Montague-Drake R, Lowe A, Saunders D, Felton A, Steffen W, Munro N, Youngentob K, Gillen J, Gibbons P, Bruzgul J, Fazey I, Bond S, Elliott C, Macdonald B, Porfirio L, Westgate M, Worthy M (2009) Climate change conservation and management: an assessment of the peer-reviewed scientific journal literature. Biodivers Conserv 18:2243-2253

Geßler A, Keitel C, Kreuzwieser J, Matyssek R, Seiler W, Rennenberg H (2007) Potential risks for European beech (Fagus sylvatica) in a changing climate. Trees 21:1-11

Gross M (2008) Return of the wolf: ecological restoration and the deliberate inclusion of the unexpected. Environ Politics 17:115-120

Gross M, Hoffmann-Riem H (2005) Ecological restoration as a real-world experiment: designing robust implementation strategies in an urban environment. Public Underst Sci 14:269-284

Hagerman S, Dowlatabadi H, Chan KMA, Satterfield T (2010) Integrative propositions for adapting conservation policy to the impacts of climate change. Glob Environ Change 20(2):351-362

Hampe A, Jump AS (2011) Climatic relicts: past present future. Annu Rev Ecol Evol Syst 42:313-333

Hannah L (2008) Protected areas and climate change. Ann N Y Acad Sci 1134:202-212

Hannah L, Midgley GF, Lovejoy T, Bond WJ, Bush M, Lovett JC, Scott D, Woodward FI (2002) Conservation of biodiversity in a changing climate. Conserv Biol 16:264-268

Hoogstra MA, Schanz H (2008) How (un)certain is the future in forestry? A comparative assessment of uncertainty in the forest and agricultural sector. For Sci 54(3):316-327

Hunter ML (1996) Fundamentals of conservation biology. Blackwell Science, Cambridge

Huntley B, Collingham Y, Willis S, Hole D, (2012) Protected areas and climate change in Europe: introduction. In: Ellwanger G, Ssymank A, Paulsch C (eds) Natura 2000 and Climate Change A challenge Naturschutz und Biologische Vielfalt Bonn: Bundesamt für Naturschutz, pp 29-47

Jones S, Fischhoff B, Lach D (1999) Evaluating the science-policy interface for climate change research. Clim Change 43:581-599

Jump AS, Hunt JM, Peñuelas J (2006) Rapid climate change-related growth decline at the southern rangeedge of Fagus sylvatica. Glob Change Biol 12:2163-2174

Jump AS, Mátyás C, Peñuelas J (2009) The altitude-for-latitude disparity in the range retractions of woody species. Trends Ecol Evol 24:694-701

Jump AS, Cavin L, Hunter P (2010) Monitoring and managing responses to climate change at the retreating range edge of forest trees. J Environ Monit 12:1791-1798

Kramer K, Degen B, Buschbom J, Hickler T, Thuiller W, Sykes MT, de Winter W (2010) Modelling exploration of the future of European beech (Fagus sylvatica) under climate change-range abundance genetic diversity and adaptive response. For Ecol Manage 259:2213-2222

Lawton JH (2007) Ecology politics and policy. J Appl Ecol 44:465-474

Lorimer J, Driessen C (2013) Wild experiments at the Oostvaardersplassen: rethinking environmentalism in the anthropocene. Trans Inst Br Geogr. doi:10.1111/tran12030

Maxime C, Hendrik D (2011) Effects of climate on diameter growth of co-occurring Fagus sylvatica and Abies alba along an altitudinal gradient. Trees 25:265-276 
McCright AM, Dunlap RE (2011) The politicization of climate change and polarization in the American public's view of global warming 2001-2010. Sociol Q 52(2):155-194

Meffe GK (1998) Conservation biology: into the millennium. Conserv Biol 12:1-3

Memmler M, Winkel G (2007) Argumentative Politikberatung in der Naturschutzpolitik. In: Krott M, Suda M (eds) Macht Wissenschaft Politik?. Erfahrungen aus der wissenschaftlichen Beratung im Politikfeld Wald und Umwelt, VS-Verlag für Sozialwissenschaften Wiesbaden, pp 203-244

Milad M, Schaich H, Bürgi M, Konold W (2011) Climate change and nature conservation in Central European forests: a review of consequences concepts and challenges. For Ecol Manage 261:829-843

Miles MB, Huberman M (1994) Qualitative data analysis: an expanded sourcebook. Sage Publications, Thousand Oaks

Palmer MA (2012) Socioenvironmental sustainability and actionable science. Bioscience 62(1):5-6

Parmesan C (2006) Ecological and evolutionary responses to recent climate change. Annu Rev Ecol Evol Syst 37:637-669

Pearson RG, Dawson TP (2003) Predicting the impacts of climate change on the distribution of species: are bioclimate envelope models useful? Glob Ecol Biogeogr 12(5):361-371

Peñuelas J, Ogaya R, Boada M, Jump AS (2007) Migration invasion and decline: changes in recruitment and forest structure in a warming-linked shift of European beech forest in Catalonia (NE Spain). Ecography 30:830-838

Peñuelas J, Sardans J, Estiarte M, Ogaya R, Carnicer J, Coll M, Barbeta A, Rivas-Ubach A, Llusià J, Garbulsky M, Filella I, Jump AS (2013) Evidence of current impact of climate change on life: a walk from genes to the biosphere. Glob Change Biol 19:2303-2308

Petrokofsky G, Brown ND, Hemery GE (2013) Matching a scientific knowledge base with stakeholders' needs: the T10Q project as a case study for forestry. For Policy Econ 37:29-36

Pigott CD, Pigott S (1993) Water as a determinant of the distribution of trees at the boundary of the mediterranean zone. J Ecol 81:557-566

Piovesan G, Biondi F, Filippo AD, Alessandrini A, Maugeri M (2008) Drought-driven growth reduction in old beech (Fagus sylvatica) forests of the central Apennines Italy. Glob Change Biol 14:1265-1281

Rabasa SG, Granda E, Benavides R, Kunstler G, Espelta JM, Ogaya R, Peñuelas J, Scherer-Lorenzen M, Gil W, Grodzki W, Ambrozy S, Bergh J, Hódar JA, Zamora R, Valladares F (2013) Disparity in elevational shifts of European trees in response to recent climate warming. Glob Change Biol 19:2490-2499

Rennenberg VH, Seiler W, Matyssek R, Gessler A, Kreuzwieser J (2004) European beech (Fagus sylvatica) - a forest tree without future in the south of Central Europe? Allgemeine Forst Und Jagdzeitung 175:210-224

Robertson DP, Hull RB (2001) Beyond biology: toward a more public ecology for conservation. Conserv Biol 15(4):970-979

Roux DJ, Rogers KH, Biggs HC, Ashton PJ, Sergeant A (2006) Bridging the science-management divide: moving from unidirectional knowledge transfer to knowledge interfacing and sharing. Ecol Soc 11:4

Sarewitz D (2004) How science makes environmental controversies worse. Environ Sci Policy 7(5):385-403

Schut M, Leeuwis C, Van Paassen A, Lerner A (2011) Knowledge and innovation management in the policy debate on biofuel sustainability in Mozambique: what roles for researchers? Knowl Manage Dev J 7(1):45-64

Sjölund J, Jump AS (2013) The benefits and hazards of exploiting vegetative regeneration for forest conservation management in a warming world. Forestry. doi:10.109310/forestry/cpt030

Spiggle S (1994) Analysis and interpretation of qualitative data in consumer research. J Consumer Res 21(3):491-503

Stevanov M, Böcher M, Krott M, Krajter S, Vuletic D, Orlovic S (2013) The research, integration and utilization (RIU) model as an analytical framework for the professionalization of departmental research organizations: case studies of publicly funded forest research institutes in Serbia and Croatia. For Policy Econ 37:20-28

Sutherland WJ, Pullin AS, Dolman PM, Knight TM (2004) The need for evidence-based conservation. Trends Ecol Evol 19(6):305-308

Turnhout E, Hisschemöller M, Eijsackers H (2008) Science in Wadden Sea policy: from accommodation to advocacy. Environ Sci Policy 11:227-239

Turnhout E, Stuiver M, Klostermann J, Harms B, Leeuwis C (2013a) New roles of science in society: different repertoires of knowledge brokering. Sci Public Policy 40:354-365

Turnhout E, Waterton C, Neves K, Buizer M (2013b) Rethinking biodiversity: from goods and services to 'living with'. Conserv Lett 6:154-161

Van Mierlo B, Regeer B, Van Amstel M, Arkesteijn M, Beekman V, Bunders J, De Cock Buning T, Elzen B, Hoes AC, Leeuwis C (2010) Reflexive monitoring in action a guide for monitoring system 
innovation projects. Communication and Innovation Studies, WUR; Athena Institute, VU, Wageningen/Amsterdam

Wadsworth Y (1998) What is participatory action research? Action research international, paper 2. Available on-line: http://www.aral.com.au/ari/p-ywadsworth98.html. Accessed 6 Feb 2014

Wagner S, Nocentini S, Huth F, Hoogstra-Klein M (2014) Coping with uncertainty: exploring two forest management strategies with impact on service provisioning under climate change. Ecol Soc 19:32

Walther GR, Post E, Convey P, Menzel A, Parmesan C, Beebee T, Fromentin JM, Hoegh-Guldberg O, Bairlein F (2002) Ecological responses to recent climate change. Nature 416:389-395

Walton DWH, Gray AJ (1991) Ecology and government policies. Trends Ecol Evol 6:144-145

Weingart P, Engels A, Pansegrau P (2000) Risks of communication: discourses on climate change in science politics and the mass media. Public Underst Sci 9:261-283

Wesselink A, Buchanan K, Georgiadou Y, Turnhout E (2013) Technical knowledge discursive spaces and politics at the science-policy interface. Environ Sci Policy 30:1-9

Winkel G, Gleißner J, Pistorius T, Sotirov M, Storch S (2011) The sustainably managed forest heats up: discursive struggles over forest management and climate change in Germany. Crit Policy Stud 5(4):361-390

Woodward FI (1987) Climate and plant distribution. Cambridge University Press, Cambridge 